\title{
REFERRAL TO THE COURT AFTER THE COMPLETION OF CRIMINAL PROSECUTION
}

\author{
Fănică CERCEL \\ fanicacercel@yahoo.com \\ UNIVERSITY OF BUCHAREST, ROMANIA
}

\begin{abstract}
After the criminal prosecution is completed, the indictment is the act of referring the court (not the inculpation, as in the previous regulation, the prosecutor's ordinance being the only procedural act in this respect), and when it also includes, in its contents, solutions for closing or waiving the prosecution, the court is not also referred for the judgment of those, even if they were described in the presentation of the case and are related to the deed brought before the court for judgment. This act of indictment is issued by the prosecutor only if he is convinced that three conditions are met cumulatively - the deed exists, it was committed by the defendant and he is criminally liableotherwise, he has a solution of non-adjudication or can appreciate on the opportunity to abandon criminal prosecution. As a novelty in the current Code of Criminal Procedure, the Guilty Plea/Agreement on the Recognition of Guilt is an exception to the principles of truth and legality, being adopted in our judicial system for pragmatic reasons, being similar as an institution to that of other criminal procedural systems on the continent. The guilty party is the prosecutor and the defendant, the latter being both a natural person and a legal person, as procedural rules do not differ in this respect. The interpretation of Article 478 par. 1 of the Criminal Procedure Code: "the defendant and the prosecutor may conclude an agreement" implies that neither of the two holders will be compelled to enter into an agreement initiated by the other.
\end{abstract}

\section{KEYWORDS:}

Completion of criminal prosecution, indictment, agreement on recognition of guilt/guilty plea, referral, court

\section{Introduction}

Completion (and purpose) of the criminal prosecution involves solving the case and bringing it before a court, at which moment the prosecutors cease their activity, following the prosecutor's disposition papers.

Bringing criminal legal dispute before the court, after the criminal investigation is carried out, is done either by issuing the accusation/indictment by the prosecutor, by entering a guilty plea agreement.

However, the difference between the two methods is essential, since the prosecutor's indictment is the act of referring the court, which is entrusted with the trial of the criminal case, while the 
agreement on the recognition of guilt is a special procedure, the judge being able to admit or to reject it, being excluded the judicial inquiry.

\section{Arraignment}

Once the criminal prosecution has been exhausted, the criminal investigating authorities, after drawing up the report with the appropriate proposal, cease their activity, only the prosecutor having at this time duties in relation to the case file.

After performing, within the criminal prosecution, the procedural acts of verifying the referral, initiation of the criminal prosecution, commencement of the criminal action and administration of the evidence, this stage is concluded by the issuance of a solution.

If the prosecutor ascertains the existence of any of the cases provided by article 16 par. 1 in the Criminal Procedure Code, he orders the dismissal of the case in question, and, if the offense referred was committed by the defendant, under the type of the guilt provided by the law, he orders the indictment of the case.

\subsection{Indictment - act of referral}

Unlike the previous regulation, the indictment is only the act of referring the court and not an inculpation, the prosecutor's ordinance being the only procedural act in this regard.

The only exception is the situation of the offense of audience, when the prosecutor declares that he initiates the criminal prosecution against the defendant, the procedural act, which reflects the procedural act ordered by the prosecutor, being the closing of the hearing.

In this context, the order to initiate criminal prosecution becomes a complex act, establishing the extent and the limits of criminal prosecution, as well as the limits of the subsequent trial of the case.

When the indictment also includes, in the presentation, solutions to close or waive prosecution, the court is not hearing and judging them, even if they were described in the presentation and related to the deed under judgment (Volonciu, 2014).

A special procedure is the Agreement on the recognition of guilt/Guilty Plea (art. 478-488 of the Criminal Procedure Code), which is written and signed by the prosecutor, the defendant and his attorney, an agreement that constitutes the act of referring the court.

\subsection{Issuing the indictment}

When the criminal prosecution is completed and the evidence shows that the deed exists, was committed by the defendant and he is criminally liable, the prosecutor issues the indictment by which he orders the indictment.

This act of disposition is issued by the prosecutor only if he is convinced that the three conditions are fulfilled, otherwise he has a solution of non-adjudication or can appreciate on the opportunity to abandon criminal prosecution.

The jurisdiction of the court belongs exclusively to the prosecutor, since the criminal investigation bodies never enter into direct relations with the court, a situation which is valid only in criminal cases (Volonciu, 1994). Unlike the previous regulation, when the criminal proceedings may be ordered at the same time as the prosecution, the indictment is merely an act of referring the court, not an act of inculpation, the prosecutor's ordinance being the only procedural act in this respect.

The only exception is the situation of the offense of audience, when the prosecutor declares that he initiates the criminal action against the defendant, the procedural act, which reflects the procedural act ordered by the prosecutor, being the closing of the hearing.

In this context, the ordinance to initiate criminal prosecution becomes a complex act, establishing the extent and the limits of the criminal prosecution, as well as the limits of the subsequent trial of the case. 
The referral to the court, as well as the arraignment whose legal consequence it is - a provision which has effect only if it is included in the indictment, is the exclusive competence of the prosecutor, except as provided by art. 341 , paragraph 7 , point 2 , letter $\mathrm{c}$ of the Criminal Procedure Code.

The Preliminary Chamber Judge hearing a complaint against non-adjudication in a case in which the criminal prosecution was initiated, by admitting the complaint, may order the commencement of the trial.

In doctrinal theory, there are opinions that this substitution of the prosecutor (who does not notify the court) in issuing this disposition constitutes an infringement of the principle of separation of judicial functions (Zarafiu, 2015).

The indictment, as a stage of the criminal prosecution, is the link between this phase, which it concludes, and the stage of the trial, which precedes and initiates, in which the criminal trial will be completed (Volonciu, 2014).

After this stage, the prosecutor can no longer take any action and can no longer intervene in the conduct of subsequent procedural activities, being dismissed as a criminal investigative body.

Consequently, issuing the indictment and bringing the case to trial simultaneously produce two important legal effects: a positive effect - the court's referral, and a negative one - the dismissal of the criminal prosecution bodies, thus operating a transfer of functional competence, from the prosecution body to the court of judgment (Zarafiu, 2015).

The indictment is a complex act, the prosecutor being able to order, in respect of other suspects or defendants or for other offenses, the solution of closing or dismissal of criminal prosecution, in which case there is no longer an ordinance for these solutions of non-arraignment.

Also, for other persons or other offences, it may be ordered to divest the case, resulting in the formation of a new criminal file, or to divest and decline the competence to solve the newly filed file in favor of another prosecutor's office, which competent from material, territorial or by the quality of the person perspective.

In the introductory part of the indictment, we find the same terms, as well as in ordinances - the name of the prosecutor's office and the date of issue, the case number, the name, surname, the quality and the signature of the person who made it.

By inserting these elements, it is possible to verify the competence of the prosecutor, his compatibility, observance of the procedural deadlines for drafting or sending the file to the court.

Of particular importance, in terms of the lawfulness of the referral, are the references to the data on the person and identity of the defendant, which must be certified by official documents, and it is not possible for them to be reported by witnesses or confirmed by close persons.

In this situation, the High Court of Cassation and Justice has ruled that bringing a person without a clearly identifiable identity to court is illegal and the court, being unlawfully invested, cannot solve this problem as a prior matter (HCCJ, 2012).

Regarding its content, the elements of which are provided by Article 328 of the Penal Code, the indictment ordering the arraignment of the defendant and the referral to the court must relate only to the offence and the defendant (the defendants) for which the criminal prosecution was carried out and the criminal action was initiated, while a person who did not benefit from the procedural rights and guarantees of this stage of the criminal proceedings cannot be sued.

The disposition of arraignment from the indictment must be consistent with the order to continue to prosecute the suspect and the order to initiate the criminal action, on the offence, its legal classification and the identity of the defendant.

This aspect is particularly important because the indictment, as an act of referring the court, points out the object of 
the judgment, thus determining the issues to be deduced from the judicial investigation, so exceeding the limits set in the course of the criminal prosecution implies the unlawfulness of the referral act.

In this respect, the European Court of Human Rights also ruled (ECHR, 1989, 2000, 2007).

The responsibility of clear delimitation of the judgment's subject lies with the prosecutor, as the titular of the criminal action, and the judge is not entitled to do this delimitation because it is incompatible with his jurisdiction.

The reference to the deed or offences deducted from the judgment should not be generic or abstract, but should refer to the concrete circumstances in which they were committed, the place and time, the means used and the purpose or the motive for which they were committed.

Presentation of the offense(s) must be backed up by references to evidence, to the explanations given by the defendant, when he acknowledged the offense or, when he did not admitted, to the objections and defense invoked, as well as to the evidence that overcomes these defenses.

If the prosecution has been carried out in respect of several offences and several persons, the prosecutor will draw up a single indictment, even if he adopts different solutions - for some deeds or persons it is ordered arraignment and for others is ordered the closing or dismissal of criminal prosecution.

It may also be ordered to divest the case, with respect to certain deeds and certain perpetrators, or to decline the jurisdiction.

It is important, however, in this case that each deed and each person are described separately, clearly and unequivocally distinguishing each person's contribution to the criminal activity.

Moreover, the NCPC (New Criminal Procedure Code) expressly regulates the possibility of including in the indictment the proposal to take precautionary measures or preventive measures.
A controversial problem in doctrine and, until 2001, in the judicial practice was the court's referral with an act not mentioned in the indictment, but described in its initial presentation of the case, with reference to the evidence on which the allegation is based.

Initially, it was appreciated that as long as the act was described in the indictment and confirmed by the administered evidence, the court must consider itself legally bound to hear it, even if it was not passed on to the indictment (Supreme Court, 1996, 1999).

Such a broad interpretation of the provisions on the judgment's subject at first instance, on the facts contained in the indictment's initial presentation of the case, although not mentioned either as deeds or under some legal classification, is likely to cause doubt regarding the prosecutor's intention to refer the case to the court and about these offences.

This doubt arises, on the one hand, from the fact that for some of the deeds described in the indictment, solutions of non-arraignment may be adopted and, on the other hand, the prosecutor's procedural act must be found in the procedural act of ordering it.

A different situation is the detention in the indictment of an incorrect legal classification of the offense for which the referral was ordered, in which case the referral notice remains valid, legally drawn up.

Legal classification of the offense by the prosecutor is provisional, subject to judicial review, the court being able to censor and to change it either when found to be erroneous in relation to the offense pursued, or when that change is necessary because of modification in the actual state of the facts, after the court has been notified and the evidence has been handled.

If the offense incriminating the defendant is described in the indictment in detail, with all the elements that have criminal implications, the object of judgment being thus clearly outlined, the 
wrongful legal classification is irrelevant, whether due to using a legal text inapplicable to the case, or referring to legal provisions that does not regulate the respective offence as crime.

According to Article 328 of the Penal Code, the indictment must also include evidence and samples of evidence. The referral must not, however, be limited to their enumeration or mere presentation, but it is necessary to analyze and interpret them so that the existence of the offence, its author, as well as the concrete circumstances in which it was committed to become obvious.

The analysis should provide the arguments for which certain evidence is invoked, while others are removed and the defense formulated by the defendant is either retained, or shall be countered and removed, with appropriate reasoning.

In addition to the arraignment, the indictment (in the initial presentation) includes references to court costs, preventive or precautionary measures, or possible security measures.

\subsection{Verifying the legality and validity of the indictment}

In the practice of the courts, it was found that there is no unitary point of view regarding the verification of the lawfulness and validity of the act of arraignment, if the filing of the indictment of the competent court is made by address, under the signature of the first prosecutor, to the general prosecutor of the prosecutor's office within the Court of Appeal or the hierarchically superior prosecutor, with reference to Article 264, Para. 3, in the Penal Code from 1968.

Following the admission of the appeal in the interest of the law declared by the Prosecutor General of the Prosecutor's Office attached to the High Court of Cassation and Justice, the supreme court held that the provisions of art. 264, para. (3) of the Criminal Procedure Code is to be interpreted as meaning that the indictment must contain the words "verified in terms of legality and validity" and the absence of such a reference entails the irregularity of the referral, applicable provisions and the current rules of criminal procedure.

In this regulation, as well as in the previous one, the indictment is verified and confirmed by the hierarchically superior prosecutor. The novelty that guarantees the rights of defense concerns the communication of the indictment to each defendant in the case, and his translation when necessary, so that any defendant can know the accusation brought to him, unlike the previous regulation when communicated only to the defendant arrested or detained.

The indictment is verified by the First Prosecutor of the Prosecutor's Office or by the General Prosecutor of the Prosecutor's Office attached to the Court of Appeal, and when it was drawn up by the Prosecutor's Office by the hierarchically superior prosecutor.

At the Prosecutor's Office attached to the High Court of Cassation and Justice, the indictment is verified by the Chief Prosecutor of the Section, and when it was drawn up by the latter, is verified by the General Prosecutor.

According to Art. $22^{2}$ of the Government Emergency Ordinance (G.E.O.) no. 43/2002, the indictments drafted by the prosecutors within the territorial services of the National Anticorruption Directorate are checked by the chief prosecutors of these services, the ones prepared by the chief prosecutors of the territorial services, as well as those drawn up by the prosecutors within the central structure of the National Anticorruption Directorate are checked by chief prosecutors of the sections. When the indictments are drawn up by chief prosecutors of the National Anticorruption Directorates, the verification is done by the chief prosecutor of that department.

In the The Directorate for the Investigation of Organized Crime and Terrorism (DIICOT) structures, the 
indictments drawn up by the prosecutors within the territorial offices and services of the Directorate for the Investigation of Organized Crime and Terrorism are checked by the chief prosecutors of these services or offices, while the indictments drawn up by Chief Prosecutors of Territorial Offices are checked by Chief Prosecutors of Territorial Services.

The indictments drafted by Chief Prosecutors of Territorial Services, as well as prosecutors within the central structure of the Directorate for the Investigation of Organized Crime and Terrorism, are verified according to the specialization of the Chief Prosecutors of these Services. When the indictments are drawn up by chief prosecutors of the services within the central structure of the Directorate for the Investigation of Organized Crime and Terrorism, the verification is done by the Chief Prosecutor of this Department.

There is no time limit for verifying the legality and validity of the indictment, the only provision to this effect referring to cases with detainees, where the verification is made as a matter of urgency before the expiry of the preventive arrest.

The absence of such a check invalidates the court's referral, a situation which the preliminary chamber judge ends by classifying the case, still the hierarchically superior prosecutor may request the restitution of the case and, after verifying the indictment, he will appreciate the legality and validity of the case.

After verifying the indictment, the hierarchically superior prosecutor may ascertain the legality and validity of the indictment or issues that affect its legality and/or validity, or may observe material misstatements or errors.

In the first situation, after confirming the indictment and signing the address, the case file is sent to the court, to the preliminary chamber judge.

In the second case, assessing the criminal prosecution as incomplete or unlawful, he refuses to justify the indictment (art. 304) and returns it to the prosecutor who has drawn up the file together with the case file with a view to reconsider or complete the criminal prosecution.

In the third situation, noting that there are no issues of illegality and groundlessness, but only reformulations or correction of typing errors, he returns it to the prosecutor to make the necessary changes.

\section{Agreement on the recognition of guilt/guilty plea}

The institution of Agreement on the Recognition of Guilt is regulated in Art. 478-488 in terms of the parties involved and its scope, the procedure and the solutions which the court may give, as well as the means of appeal against the verdict.

It is a novelty in the current Criminal Procedure Code, constituting an exception to the principles of truth and legality, being adopted in our judicial system for pragmatic reasons, being similar, as an institution, to that of other criminal procedural systems on the continent.

The guilty plea holders are the prosecutor and the defendant, the latter being both a natural person and a legal person, as procedural rules do not differ in this respect.

The fact that only the defendant (not the suspect) can conclude such an agreement has as a consequence the obligation to initiate the criminal action, since the agreement/plea is subject to confirmation by the court which verifies both the validity of the consent and the state of facts established during the criminal investigations, thus it is necessary to have minimum evidence proving an offense committed by the investigated person.

Also, such agreements cannot be concluded by defendants who committed the act when they were minors, a ban imposed by the legislator as a measure to protect them.

Although one of the holders of the agreement on the recognition of guilt, the 
prosecutor dealing with the case can not establish its delimitations which are subject to the prior and written approval of the hierarchically superior prosecutor, a condition which derives from the principle of hierarchical control under which the Public Ministry operates..

However, the hierarchically superior prosecutor cannot determine the quantum of the punishment and the way it is executed, as it would be in contradiction with the reasoning of the institution, no elements of negotiation being at the reach of the prosecutor who carried out the criminal investigation or supervised the investigations.

Article 478 para. 3 of Criminal Procedure Code provides that the initiation of the agreement on the recognition of guilt can be made by both the prosecutor and the defendant without any restriction or priority in this respect.

Judicial doctrine still questions whether the prosecutor is obliged to accept to negotiate with the defendant any agreement initiated by the latter, supporting either the possibility of the prosecutor to refuse, or, on the contrary, his obligation to accept the initiation of the negotiation procedure.

From the interpretation of the provisions of art. 478 par. 1 of Criminal Procedure Code - "the defendant and the prosecutor can conclude an agreement" it follows that neither of the two holders can be compelled to enter into an agreement initiated by the other.

Furthermore, the meaning of the term "agreement" implies that both holders of the agreement are agreeing with it.

The agreement on the recognition of guilt must necessarily refer to the recognition of the commission of the offense, the acceptance of its legal classification, and the manner, quantum and form of execution of the punishment.

However, the law limits the applicability of this institution only to offenses for which either the punishment of the fine or the imprisonment of no more than 15 years is prescribed and imposes compulsory legal assistance upon the conclusion of the agreement on the recognition of guilt (Article 480 of the Penal Code).

We consider that this condition, for the purpose of concluding the agreement on the recognition of guilt, as the punishment stipulated by the law to be at most 15 years, limits unjustifiably (and somewhat discriminatory) the application of this institution.

Removing this condition from the law would not have any effect on the two holders of the agreement because it is subject to validation by the court anyway.

The written form and the content of the agreement on the recognition of guilt are provided by art. 481 and art. 482, and, after its conclusion, it is submitted to the hierarchically superior prosecutor's opinion (Article 478 paragraph 2 of the Penal Code).

This subsequent opinion is practically unnecessary because, on the one hand, it complies with the limits previously established by the hierarchical prosecutor and, on the other hand, the legality of the agreement is verified by the court.

The civil party (the injured party) does not participate in the conclusion of such an agreement and, where it is accepted by the court, civil claims can be settled later by an action of this nature, except where the parties conclude a mediation transaction or agreement, in which case the court takes notice of them through a verdict.

When several people were investigated, the agreement on recognition of guilt is concluded with each one, the result of which is recorded in a single document.

If, however, not all defendants accept the conclusion of such an agreement, the case will be disunited with regard to the others, who are still granted the presumption of guilt until the final conviction. 
If the guilty plea agreement is concluded first and the court is notified for its admission, the prosecutor will order the case to be disunited by ordinance with respect to the other defendants, and if the indictment is first drawn up before the agreement on the recognition of guilty, the separation of the case will be disposed of by the act of referral.

Defendants with whom the agreement has been concluded may be heard as witnesses in the disputed case, but, in this case, they are not admitted by the court and their statements cannot be used against them.

In the case of plurality of offenses, each punishment is individually negotiated, as well as the amount of the resulting punishment, as the law imposes also the punishment's form of execution as an object of the agreement.

It should be noted that in the situations where the criminal cases are solved in this way, the criminal investigation is not "finished", according to the provisions of art. 321 and seq. of the Criminal Procedure Code since it is not necessary to have evidence proving, beyond reasonable doubt, the culpability of the defendant, the existence of some solid evidence that the criminal act was committed by him, corroborated with his recognition, being sufficient legally.

The file in which an agreement on the recognition of guilt has been concluded is sent directly to the court which has jurisdiction to adjudicate the substance of this case, without passing through the preliminary chamber phase and the legality of the evidence administered during the prosecution is not called into question.

The court rules on the admission of the agreement in a non-controversial procedure, but with the hearing of the prosecutor, the defendant, his lawyer and the civil party, if present, without further request or exception of evidence, except for the possibility of submission of documents in circumstantial terms.

After the agreement on the recognition of guilty has been concluded and until the admission procedure before the court, the defendant can withdraw his/ her consent expressed during the criminal prosecution phase.

The admission by the court of the agreement does not amount to a simple ratification of it but presupposes the individualization and application of the punishment, according to the general and special criteria of individualization specific to the judicial function.

\section{Conclusions}

Completion of criminal prosecution is one of the most important moments of the criminal trial, both for criminal investigation bodies and prosecutors, and (especially) for the defendant.

This moment does not mean the depletion of the criminal prosecution, as a stage of the criminal trial, but represents the finalization of the criminal investigation activity and of the administration of evidence, after which the file is submitted to the prosecutor in order for him to pronounce on the proposal made by the criminal investigation body.

If the prosecutor has carried out the criminal investigation, the distinction is no longer made between the moment when the criminal investigations are terminated and the pronouncement of the prosecutor is made, the solution ordered by him indicating the depletion of the criminal prosecution as a phase of the criminal trial.

Referral to the court is particularly important because only in this way the person who committed an offense can be held criminally liable, while the solutions to non-arraignment in court represent a negative solution to the criminal action. 


\section{REFERENCES}

European Court of Human Rights also ruled (ECHR). (1989). ECHR decision. Kamasinski against Austria.

European Court of Human Rights also ruled (ECHR). (2000). ECHR decision. Mattoccia against Italy.

European Court of Human Rights also ruled (ECHR). (2007). ECHR decision. Zaicevs against Latvia.

High Court of Cassation and Justice (HCCJ). (2012). Decision no. 2102/14.06.2012. Bucharest.

Romanian Government (2002). The Government Emergency Ordinance (G.E.O.) no. 43/2002, regarding the National Anticorruption Prosecution Office. Art. $22^{2}$. Bucharest.

Parchetul de pe lângă Tribunalul Mehedinţi. (2019). Dosar penal nr. 54/P/2019.

Supreme Court. (1996). Decision no. 42 and decision no. 176. Bucharest.

Volonciu, N. (1994). Tratat de procedură penală, Partea special. Vol. II, Bucureşti: Editura Paideea.

Volonciu, N. (2014). Noul Cod de procedură penală, comentat. Bucureşti: Editura Hamangiu.

Zarafiu, A. (2015). Procedură penală. Partea general, Partea special, Ediţia a II-a. Bucureşti: Editura C.H. Beck. 